\title{
1 Alternative and Sustainable Solvents for Green Analytical Chemistry
}

Ombéline Claux ${ }^{1,2}$, Cyrille Santerre ${ }^{3,4}$, Maryline Abert-Vian ${ }^{1}$, David Touboul ${ }^{4}$,

4 Nadine Vallet ${ }^{3}$, Farid Chemat ${ }^{1, *}$

$5 \quad{ }^{1}$ Avignon University, INRAE, UMR 408, GREEN Extraction Team, F-84000 Avignon, France

$6 \quad{ }^{2}$ Pennakem Europa, 224 avenue de la Dordogne, F-59944 Dunkerque, France

7 Institut Supérieur International Parfum Cosmétique Arômes, Plateforme scientifique, 34-36

8 rue du parc de Clagny, 78000 Versailles, France

$9{ }^{4}$ Université Paris-Saclay, CNRS, Institut de Chimie des Substances Naturelles, UPR 2301,

10 91198, Gif-sur-Yvette, France

11 * Corresponding author: farid.chemat@univ-avignon.fr

13 Abstract

14 Analytical chemistry relies massively on solvents, which are generally petroleum-based and 15 have hazardous effects. The ideal alternative solvents suitable for analysis should have high 16 selectivity, solvency, low toxicity and low environmental impacts, be easily biodegradable and recyclable and obtained from renewable resources at a reasonable price. Obviously, finding the ideal solvent that meets all the aforementioned requirements is a big challenge. Therefore, the selection of the optimum solvent will always be a compromise depending on the extraction procedure, the analytical method, the matrix and the target molecules. In this current opinion we provide an instantaneous picture of current knowledge on alternative and sustainable solvents used in analytical laboratories either for sample preparation or analysis in terms of innovation and development of safe products and procedures.

\section{Keywords}

25 Alternative solvent, green extraction, green analysis, NADES, bio-based solvents, supercritical solvent, liquefied gases 


\section{Introduction}

The greenest and most sustainable solvent that could be used in analytical chemistry is undoubtedly no solvent. However, both sample preparation and analytical methods require solvent, to have samples in liquid form and enable convenient separation of molecules of interest. Common solvents are principally volatile organic compounds (VOCs) obtained from non-renewable petrochemical resources and suspected to be harmful to both human health and the environment. Due to the new emphasis on environmental and safety protections and the development of green chemistry, finding alternative solvents to petroleum-derived solvents has become a major concern for analytical chemists. Therefore, sustainable alternatives are getting more and more numerous and the suitable solvent needs to be chosen wisely. This current opinion is aimed to give an instantaneous picture of current knowledge on alternative and sustainable solvents (Figure 1) used in analytical laboratories either for sample preparation or analysis.

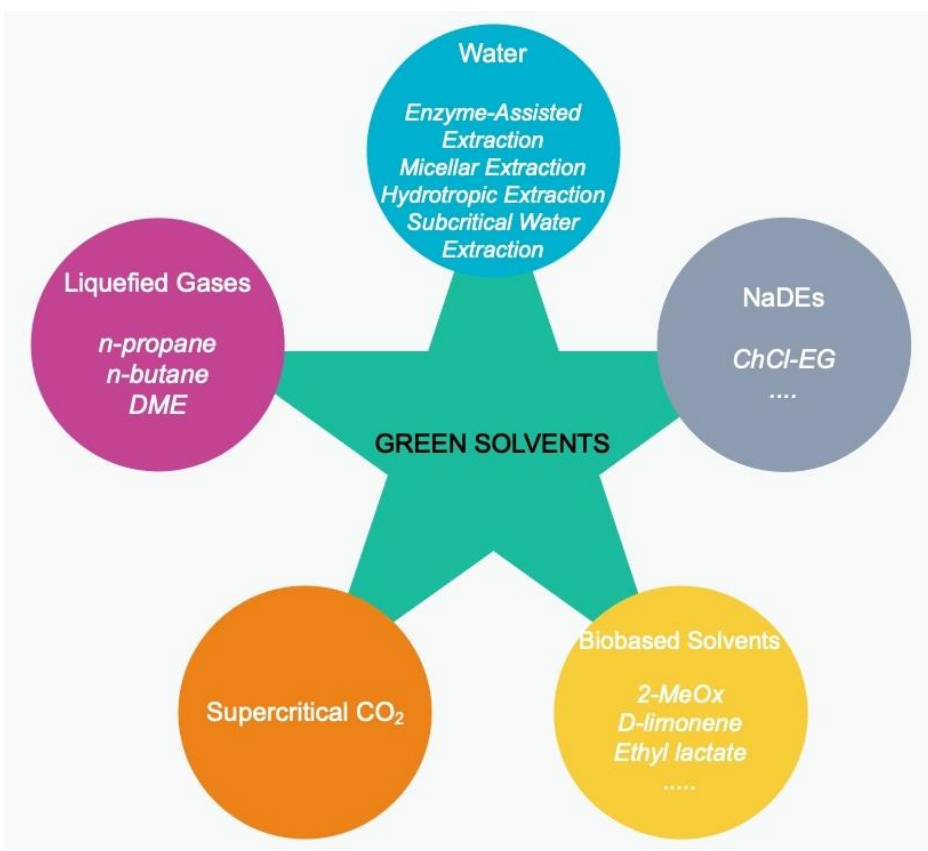

Figure 1. Alternative and sustainable solvents

\section{Alternative solvents for sample preparation}

\section{Overview of alternative solvents for sample preparation}

The common belief is generally that water is the greenest and safest solvent, partly because it is the most abundant molecule on the Earth's surface. Water also presents the advantages of having a low economical cost, being environmentally harmless and non-toxic. The simplest and most conventional way to perform extraction using water as a solvent is maceration [1]. The 
procedure can be optimized regarding soaking time, temperature and the repetition of several extraction steps to exhaust the matrix. The properties of water can be slightly modified by using specific additives. For example, the addition of enzymes can greatly improve the selectivity or the efficiency of the extraction [2]. A wide range of enzymes are available with specific properties, mode of action and operational conditions. Micellar and hydrotropic extractions also rely on water and an additional compound, respectively a surfactant and a hydrotrope. Those amphiphilic molecules can improve the solubility of hydrophobic compounds in the aqueous media by respectively forming micelles and aggregates $[3,4]$. The main difference between the two techniques is that micellar extraction resembles a two-liquid-phase extraction method (above a temperature called "cloud point" micelles become instable and two phases are formed) while hydrotropic extraction only involves a continuous liquid phase. Subcritical water extraction (SWE) can be used to extract non-polar compounds with water as well. SWE takes place at temperatures between the boiling and critical points of water, i.e. $100^{\circ} \mathrm{C}$ at 1 bar and $374.1^{\circ} \mathrm{C}$ at $221 \mathrm{bar}$, at pressures high enough to keep water in the liquid state. The polarity of subcritical water is measured by the value of its dielectric constant $\varepsilon$, which decreases as temperature increases. Therefore, by tuning water temperature at high pressure, its polarity can be modulated to become similar to those of organic solvents in order to target specific molecules of interest [5].

Natural Deep Eutectic Solvents (NADESs) are mixtures of natural solids (common primary metabolites such as sugars, organic acids, amino acids, alcohols and choline chloride [6-8]) that have melting points far below those of any of their individual components. This specificity is mainly due to the generation of intermolecular hydrogen bonds between hydrogen bond acceptors and hydrogen bond donors. NADESs are environmentally friendly and readily biodegradable as they are considered the third solvent in living cells [9]. This feature explains their high solubilizing capacity for natural products. The large number of combinations that can be made, their simple preparation and low cost are also major advantages that are encouraging research on their extraction applications.

The term "bio-based solvents" gathers a lot of biomolecules that can be sorted into three categories based on the agro-sector they are produced from: cereal/sugar, oleo-proteaginous and wood. Bio-solvents obtained from cereal or sugar sources are mainly obtained by fermentation of sweet juices and valorization of lignocellulose residues derived from cereal production wastes. In this category we can find for example ethanol [10], ethyl acetate [11], esters of lactic acid [12], derivatives of succinic acid, or furfural and its derivatives such as 2- 
methyl-tetrahydrofuran also known as 2-methyloxolane (2-MeOx) [13] or cyclopentyl methyl ether (CPME) [14]. The oleo-proteaginous bio-based solvents are produced from oilseeds (sunflower, soybean, rapeseed). It is typically the case of fatty acid esters and glycerol derivatives. The wood sector offers the possibility to produce terpene hydrocarbons such as dlimonene, $\mathrm{p}$-cymene or $\alpha$ - and $\beta$-pinene from conifers or fruit peels. Overall, a wide range of bio-based solvents are currently available and each one has its own specificities and properties. The selection of a particular solvent makes it possible to target specific molecules to extract and analyze such as polyphenols, carotenoids, aromas or lipids.

Liquefied gases are gases that can be liquefied under their own vapor pressure inside a pressurized container and under moderate pressure (1 to 100 bar). They offer the advantages of dissolving natural substances at relatively low temperatures avoiding deterioration of sensitive components and being easy to remove from the extracts due to their volatility. More and more studies report the use of liquefied gases as green solvents for extraction such as $n$ propane [15], $n$-butane [16] and dimethyl ether (DME) [17].

Supercritical fluids (SFs) are substances at conditions of temperature and pressure above their critical point. Under these conditions, the fluid phase possesses characteristics between those of gas and liquid phases. The main advantage of a SF is that its density (and hence its solvating power) can be tuned by changing its pressure and/or temperature, permitting selective extraction of target analytes. On top of that, SFs exhibit almost no surface tension making them able to penetrate microporous materials and leave almost no solvent residue in the final extract. Carbon dioxide $\left(\mathrm{CO}_{2}\right)$ is the most commonly used SF thanks to its moderate critical temperature and pressure, i.e. $31^{\circ} \mathrm{C}$ and 74 bar. Moreover, this fluid is inert, inexpensive, non-flammable, environmentally sustainable odorless and tasteless. A lot of studies report the use of supercritical $\mathrm{CO}_{2}$ for the extraction of various analytes such as essential oils, carotenoids or vegetable oils [18]. 
107 Table 1. Examples of application of alternative solvents for sample preparation ${ }^{\mathrm{a}}$

\begin{tabular}{|c|c|c|c|c|c|}
\hline Technique & Matrix & Analytes & Conditions & Analysis & Reference \\
\hline \multicolumn{6}{|l|}{ Water } \\
\hline $\begin{array}{l}\text { Conventional } \\
\text { maceration }\end{array}$ & Apple pomace & Polyphenols & $\begin{array}{l}100^{\circ} \mathrm{C}, 1 \mathrm{~h}, \mathrm{pH} 2.5, \mathrm{SLR} \\
1: 5(w / v), \text { repeated } 4 \\
\text { times }\end{array}$ & $\begin{array}{l}\text { UHPLC-DAD, } \\
\text { UHPLC-MS }\end{array}$ & {$[1]$} \\
\hline $\begin{array}{l}\text { Enzyme-assisted } \\
\text { extraction }\end{array}$ & Tomato waste & Lycopene & $40^{\circ} \mathrm{C}, 5 \mathrm{~h}, \mathrm{ESR} 0.2(v / w)$ & HPLC-DAD & [2] \\
\hline $\begin{array}{l}\text { Surfactant-assisted } \\
\text { extraction }\end{array}$ & Orange peel & Pectin & 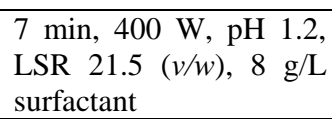 & FTIR & [3] \\
\hline $\begin{array}{l}\text { Hydrotrope } \\
\text { extraction }\end{array}$ & Rosemary leaves & Carnosic acid & $\begin{array}{l}\text { RT, } 24 \text { h, pH 2, SLR 1:10 } \\
(w / v), 30 \% \text { amphiphile } \\
\text { solution }\end{array}$ & HPLC-UV & [4] \\
\hline $\begin{array}{l}\text { Subcritical water } \\
\text { extraction }\end{array}$ & Defatted orange peels & Flavanones & 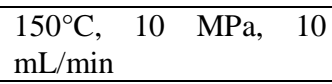 & HPLC-UV & [5] \\
\hline \multicolumn{6}{|l|}{ NADESs } \\
\hline $\begin{array}{l}\text { ChCl-MA molar } \\
\text { ratio } 1: 1\end{array}$ & $\begin{array}{l}\text { Gingko biloba leaves } \\
\text { Panax ginseng leaves }\end{array}$ & $\begin{array}{l}\text { Phenolic acids } \\
\text { Saponins }\end{array}$ & $\begin{array}{l}40^{\circ} \mathrm{C}, 1 \mathrm{~h}, \quad \text { SLR } 1: 20 \\
(w / v)\end{array}$ & HPTLC & [7] \\
\hline $\begin{array}{l}\text { ChCl-EG molar } \\
\text { ratio 1:4, } 10 \% \mathrm{w} \\
\text { water }\end{array}$ & Orange peels & Polyphenols & $\begin{array}{l}60^{\circ} \mathrm{C}, 100 \mathrm{~min}, \mathrm{SLR} 1: 10 \\
(w / v)\end{array}$ & HPLC-UV & [8] \\
\hline $\begin{array}{l}\text { ChCl-Gly molar } \\
\text { ratio } 1: 1\end{array}$ & $\begin{array}{l}\text { Byrsonima intermedia } \\
\text { leaves }\end{array}$ & Polyphenols & $\begin{array}{l}45^{\circ} \mathrm{C}, 25 \mathrm{~min}, \text { SLR 1:15 } \\
(w / v)\end{array}$ & $\begin{array}{l}\text { HPLC-DAD, } \\
\text { UHPLC-MS }\end{array}$ & [6] \\
\hline \multicolumn{6}{|l|}{ Bio-based solvents } \\
\hline$\overline{\mathrm{EtOH}}$ & Bilberry & Polyphenols & $\begin{array}{l}\text { UAE, } 24 \mathrm{kHz}, 30 \mathrm{~min} \text {, } \\
\text { SLR 1:10 }(w / v)\end{array}$ & HPTLC & [10] \\
\hline Ethyl acetate & Blackcurrant pomace & Polyphenols & $\begin{array}{l}\text { Maceration, RT, SLR } \\
1: 100(w / v) \text {, repeated } 3 \\
\text { times }\end{array}$ & HPLC-DAD & [11] \\
\hline Ethyl lactate & Turmeric & Curcuminoids & $\begin{array}{l}\text { Maceration, RT, } 30 \mathrm{~min}, \\
\text { SLR 1:1000 }(w / v)\end{array}$ & HPLC-DAD & [12] \\
\hline 2-MeOx & Lentisk fruits & Oil & $\begin{array}{l}\text { Soxhlet, } 45-60^{\circ} \mathrm{C}, 8 \mathrm{~h} \text {, } \\
\text { SLR 1:4 }(w / v)\end{array}$ & $\begin{array}{l}\text { HPTLC, GC- } \\
\text { FID }\end{array}$ & [13] \\
\hline CPME & Litsea cubeba kernels & Oil & $\begin{array}{l}\text { Reflux, BP, } 3 \mathrm{~h}, \text { SLR } \\
1: 20(w / v)\end{array}$ & $\begin{array}{l}\text { GC-FID, GC- } \\
\text { MS, HPLC-UV }\end{array}$ & [14] \\
\hline \multicolumn{6}{|l|}{ Liquefied gases } \\
\hline$n$-butane & Flaxseed & Oil & $\begin{array}{l}54^{\circ} \mathrm{C}, 0.5 \mathrm{MPa}, 1 \mathrm{~h}, \mathrm{SLR} \\
1: 20(\mathrm{w} / \mathrm{v})\end{array}$ & GC-FID & {$[16]$} \\
\hline$n$-propane & Cashew nuts & Oil & $\begin{array}{l}60^{\circ} \mathrm{C}, 8 \mathrm{MPa}, 1 \mathrm{~h}, 6 \% \mathrm{w} \\
\mathrm{EtOH}\end{array}$ & $\begin{array}{l}\text { GC-FID, GC- } \\
\text { MS, HPLC-MS }\end{array}$ & [15] \\
\hline DME & $\begin{array}{l}\text { Chaetoceros gracilis } \\
\text { Pleurochrysis } \\
\text { carterae }\end{array}$ & Lipids & $25^{\circ} \mathrm{C}, 0.59 \mathrm{MPa}, 45 \mathrm{~min}$ & GC-MS & {$[17]$} \\
\hline \multicolumn{6}{|c|}{ Supercritical fluid extraction } \\
\hline $\mathrm{CO}_{2}$ & Apple seeds & $\begin{array}{l}\text { Oil } \\
\text { Phenolic } \\
\text { compounds } \\
\end{array}$ & $\begin{array}{l}40^{\circ} \mathrm{C}, 24 \mathrm{MPa}, 140 \mathrm{~min} \text {, } \\
\text { flow rate } 1 \mathrm{~L} / \mathrm{h}\end{array}$ & $\begin{array}{l}\text { GC-FID, } \\
\text { HPLC-MS }\end{array}$ & [18] \\
\hline
\end{tabular}

${ }^{a} \mathrm{ChCl}$, choline chloride; MA, malic acid; EG, ethylene glycol; Gly, glycerol; $\mathrm{MeOH}$, methanol; EtOH, ethanol; DMC, dimethyl carbonate; 2-MeOx, 2-methyloxolane; CPME, cyclopentyl methyl ether; DME, dimethyl ether; SLR, solid:liquid ratio; LSR, liquid:solid ratio; ESR, enzyme:substrate ratio; RT, room temperature; BP, boiling point; PLE, pressurized liquid extraction; UAE, ultrasound-assisted extraction; UHPLC, ultra-high-performance liquid chromatography; HPLC, high-performance liquid chromatography; FTIR, Fourier transform infrared spectroscopy; HPTLC, high-performance thin layer chromatography; GC, gas chromatography; DAD, diode array detector; UV, ultra-violet detector; MS, mass spectrometer 
115 2-methyloxolane (2-MeOx), also known as 2-methyltetrahydrofuran, is a cyclic ether issued 116 from carbohydrates obtained from lignocellulosic biomass. 2-MeOx is produced at industrial scale from agricultural wastes as corn stover or sugarcane bagasse. Its production involves three steps: (i) a harsh acidic treatment of the material for deconstructing lignocellulose and release pentose and hexose sugar units; (ii) a biorefining process for the conversion of C5 and C6 sugar units into furfural and levulinic acid respectively; (iii) several hydrogenation reactions from furfural and levulinic acid to finally obtained 2-MeOx [19].

Recently, the potential of 2-MeOx to extract aromas from different matrices was investigated. In 2019, Ozturk et al. used 2-MeOx among other bio-based solvents to perform the extraction of limonene from orange peel residues and compared the results to those obtained with hexane [20]. At optimum conditions, it was found that 2-MeOx outperformed hexane by increasing limonene extraction yield by $40 \%$. The following year, its ability to extract volatile compounds from hop cones was also demonstrated [21]. This time again the aroma yield obtained with 2MeOx (20.2\%) was higher than what was obtained with $n$-hexane $(17.9 \%)$ and both extracts had similar compositions and olfactory profiles.

130 2-MeOx appears to be an efficient bio-based solution for preparation of color samples as well, particularly in the case of carotenoids. Its efficiency was lately evaluated to recover astaxanthin from Haematococcus pluvialis cultures [22]. 2-MeOx enabled more than $80 \%$ of carotenoid recovery in only $30 \mathrm{~min}$ and was hence one of the most effective bio-based solvent tested in 134 this study.

135 More and more studies report the efficiency of 2-MeOx for lipid extraction, either from plant 136 seeds, fruits, microalgae, microorganisms, or even animals such as larvae. As illustrations, the 137 studies of Bettaieb Rebey et al. on fennel and anise oils [23], and Ravi et al. on black soldier 138 fly larvae lipids [24] can be cited. Briefly, the papers describe that 2-MeOx enables a higher crude oil yield than the benchmark $n$-hexane and that the extracts have similar fatty acid profiles. 2-MeOx also provides extracts with higher phospholipids and total phenolic contents

141 than the conventional ones.

142 Overall, the results of recent studies on the possible use of 2-MeOx for extraction purposes 143 indicate that this bio-based solvent is suitable for eco-extraction of different analytes. Therefore, 144 it could replace hazardous petrochemical solvents as $n$-hexane, chloroform, dichloromethane 145 etc. in sample preparation stages for analysis of aromas, colors or lipids. 


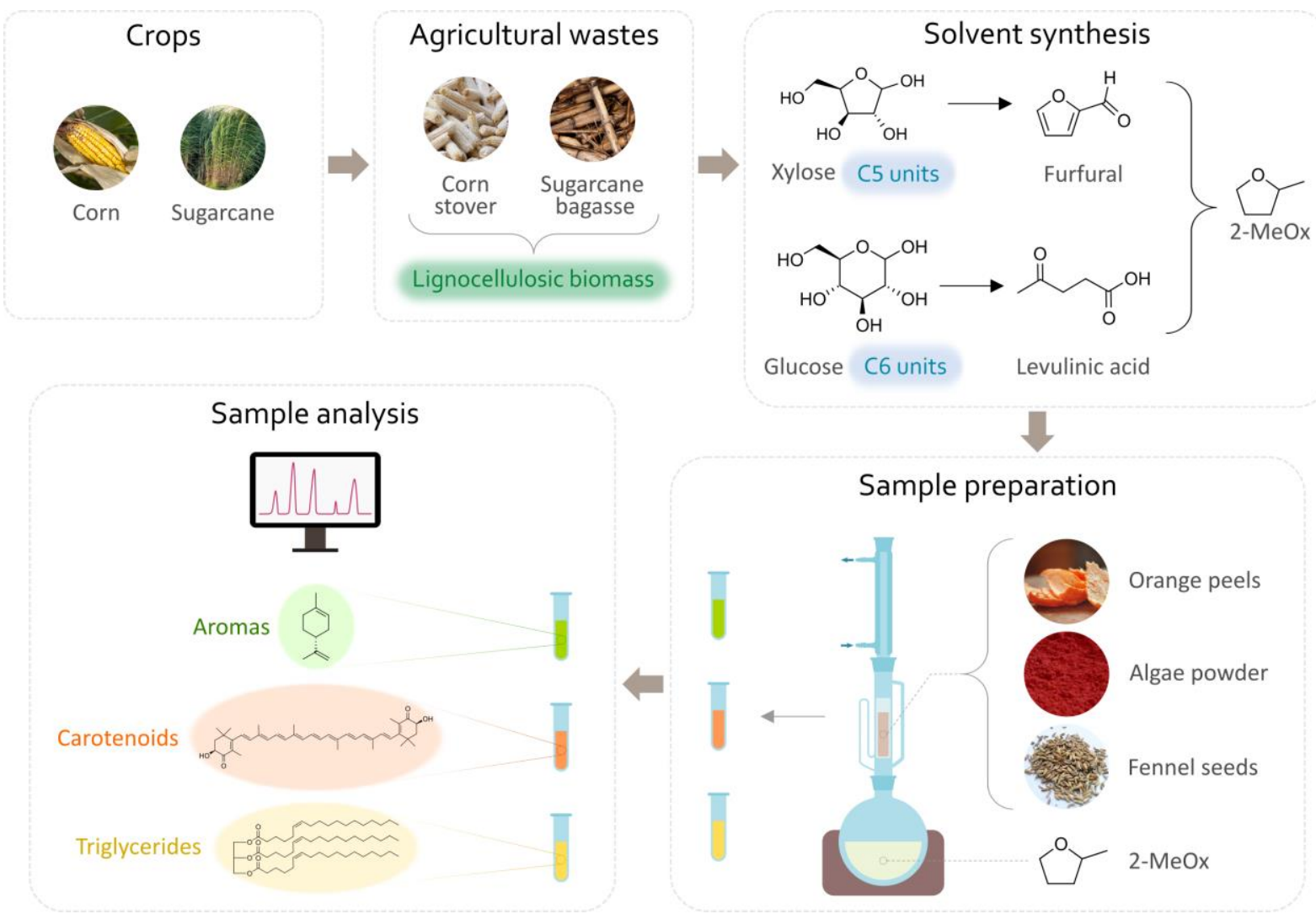

Figure 2. 2-MeOx as a bio-based alternative solvent for sample preparation in analytical 148 chemistry

\section{Alternative solvents for analysis}

Overview of alternative solvents for analysis

151 The most widely used chromatography technique in the literature is currently reverse phase 152 chromatography (RPLC) using C18 columns and binary water/acetonitrile mixtures.

153 Acetonitrile is a toxic solvent obtained as a by-product of the production of acrylonitrile, the 154 manufacture and use of which has a high environmental cost. One of the simplest alternatives 155 is the use of alcohol, particularly ethanol, as a substitute for acetonitrile. Dogan et al. [25] 156 demonstrated in 2020 the separation of pharmaceutical compounds such as famotidine, 157 paracetamol and thiocolchicoside with water + phosphate buffer / ethanol gradients with similar 158 sensitivity than methods based on water/acetonitrile mixtures. Another option is to eliminate 159 the use of acetonitrile by drastically modifying the chromatographic conditions while keeping 160 C18 stationary phase. For example, Ali et al. [26] proposed the separation of terephthalic acid 161 (TPA) contaminants (mono-, di-, and tri-carboxylic aromatic acids) by saturating the stationary 162 phase with Tween 20 (polyoxyethylene(20)sorbitan monolaurate) and eluting the compounds 163 under isocratic conditions with a mobile phase composed of acidified water ( $\mathrm{pH} 2$ ) by a 164 sulphuric acid solution. Finally, the water can also be employed as a subcritical fluid. The 
165 dielectric constant of water together with the surface tension and viscosity are decreasing when 166 increasing temperature from $25^{\circ} \mathrm{C}$ to $250^{\circ} \mathrm{C}$, meaning that subcritical water at $250^{\circ} \mathrm{C}$ has lower 167 polarity than pure methanol or acetonitrile. Therefore, Doctor and Yang [27] described the use of subcritical water with phosphate buffer at $\mathrm{pH}$ between 3.4 and 3.85 for the separation and analysis of aspirin and metformin $\mathrm{HCl}$ on $\mathrm{C} 18$ column.

170 It is also possible to eliminate the use of water and acetonitrile in micellar liquid 171 chromatography to achieve chromatographic analysis still on C18 column. Ramezani and 172 Absalan [28] published in 2019 the monitoring of melanin concentration in milk by micellar 173 liquid chromatography using a mobile phase containing a mixture of sodium dodecyl sulphate 174 (SDS) and a mixture of choline chloride-ethylene glycol-based natural deep eutectic solvent 175 (NADES), butanol, and glacial acetic acid. NADESs were firstly introduced by Choi et al. 176 (2011) [29] as a third class of liquids, unlike water and lipid phase, existing in living cells, and 177 playing a crucial role as an alternative medium for biosynthesis, transport and storage of 178 compounds with intermediate polarity. Due to their liquid stability within a wide temperature 179 range, very low volatility, chemical and thermal stability, non-flammability, and nontoxic 180 constituents, NADESs are considered as green solvents. The same methodology was then used 181 for the efficient analysis of four crucial cardiovascular drugs, optimizing in both cases the 182 composition of the mobile phase using chemometric tools [30]. Thus, Raj [31] carried out a 183 screening of NADESs as alternative solvents in thin layer chromatography (TLC) in 2020. The 184 most successful mobile phase, which enabled separation of all the tested alkaloids, was the 185 equimolar mixture of menthol and phenol with a $35 \%$ addition of methanol, avoiding the 186 classical use of acetone, chloroform or diethyl ether.

187 Beyond the elimination of acetonitrile or even water as a chromatographic solvent, 188 enantioselective or normal phase liquid chromatography (NPLC) are based on non-polar and/or 189 chlorinated organic solvents from petrochemistry for elution. The most popular approach in the 190 literature to overcome these solvents, in particular alkanes such as hexane, is the use of $\mathrm{CO}_{2}$ as 191 a supercritical fluid. Finally, agro-solvents such as limonene or 2-methyloxolane also play an 192 important role in the substitution of apolar or intermediate polarity solvents in chromatography 193 even if their report in the literature is still scarce [32]. 
195 Supercritical $\mathrm{CO}_{2}$ has a low viscosity with liquid-like densities and high solubilizing power.

196 Thus, the low viscosity and high diffusion allow separations and extractions 3 to 10 times faster

197 than in liquid chromatography with equivalent particle size, moreover reducing health and

198 environmental risks, and costs over long term. Supercritical $\mathrm{CO}_{2}$ is miscible with alcohols, in

199 particular ethanol, allowing a green approach in analytical and preparative chromatography. In

200 the latter case, the purified samples are finally solubilized in alcohol, which requires little

201 energy to evaporate, while the $\mathrm{CO}_{2}$ can be recycled up to $98 \%$ per cycle. Supercritical Fluid

202 Chromatography (SFC) is particularly suitable for the analysis of lipids, soluble in organic 203 solvents and in the initial chromatographic conditions. In particular, the work of the groups of 204 T. Bamba [33], M. Holcapeck [34] or D. Touboul [35] have demonstrated the capacity of SFC 205 to efficiently separate complex lipid mixtures (phospholipids, sphingolipids, glycolipids ...) by 206 subclasses with analytical retention times of about fifteen minutes, compared to about 45 207 minutes for classical NPLC methods using ternary mixtures of organic solvents (acetone, 208 hexane, ethyl acetate ...). Chollet et al. [35] illustrated this approach by the analysis of 209 Nannochloropsis extracts, considered as a promising alga for green industries due to its ability 210 to accumulate polyunsaturated fatty acids at a high level. These methods can be quantitative 211 within the limit of availability of pure standards for each lipid subclass. Beyond apolar analytes, 212 Ventura [36] has established that SFC is also efficient for the separation of crude therapeutic 213 peptides and peptide libraries when combining supercritical $\mathrm{CO}_{2}$ elution with methanol and 214 additives such as trifluoroacetic acid and ammonia. In the field of large-scale compound 215 purification, supercritical $\mathrm{CO}_{2}$ can be used as an eluent in flash chromatography [37], while the use of liquid $\mathrm{CO}_{2}$ in centrifugal tubes to conduct TLC has been established [38]. 
217 Table 2. Example of applications of alternative solvents for analysis ${ }^{\mathrm{a}}$

\begin{tabular}{|c|c|c|c|c|c|}
\hline Solvent & Polarity & $\begin{array}{c}\text { Proton } \\
\text { donor }\end{array}$ & Technology & Target & Reference \\
\hline \multicolumn{6}{|l|}{ Ethanol } \\
\hline Ethanol/water & Polar & Yes & HPLC & $\begin{array}{l}\text { Pharmaceutical drugs (famotidine, } \\
\text { paracetamol, thiocolchicoside), Alkaloid } \\
\text { (caffeine) }\end{array}$ & [25] \\
\hline \multicolumn{6}{|l|}{ Water } \\
\hline Liquid water & Polar & Yes & $\begin{array}{l}\text { Micellar and sub- } \\
\text { micellar liquid } \\
\text { chromatography }\end{array}$ & $\begin{array}{l}\text { TPA contaminants (mono-, di-, and } \\
\text { tricarboxylic aromatic acids) }\end{array}$ & {$[26]$} \\
\hline $\begin{array}{l}\text { Subcritical } \\
\text { water }\end{array}$ & Polar & Yes & SBWC & Pharmaceutical drugs (aspirin, metformin) & [27] \\
\hline \multicolumn{6}{|c|}{ Eutectic solvents } \\
\hline \multirow[b]{2}{*}{$\mathrm{ChCl}$ and $\mathrm{EG}$} & \multirow[b]{2}{*}{ Polar } & \multirow[b]{2}{*}{ Yes } & \multirow{2}{*}{$\begin{array}{l}\text { Modified micellar } \\
\text { chromatography }\end{array}$} & Nitrogen aromatic compound (melamine) & [28] \\
\hline & & & & $\begin{array}{l}\text { Pharmaceutical drugs (aspirin, atorvastatin, } \\
\text { metformin, metoprolol) }\end{array}$ & [29] \\
\hline $\begin{array}{l}\text { Phenolics and } \\
\text { terpenes }\end{array}$ & $\begin{array}{l}\text { Polar and } \\
\text { non polar }\end{array}$ & I & TLC & $\begin{array}{l}\text { Alkaloids (sanguinarine, coptisine, } \\
\text { chelerythrine, chelidonine, berberine) }\end{array}$ & [31] \\
\hline \multicolumn{6}{|l|}{ Agro-solvents } \\
\hline $\begin{array}{l}\text { Limonene } \\
2-\mathrm{MeOx} \\
\end{array}$ & $\begin{array}{l}\text { Non polar } \\
\text { Mid polar }\end{array}$ & $\begin{array}{l}\text { No } \\
\text { No }\end{array}$ & HPLC & Lipids (cholesteryl ester, phospholipids) & {$[32]$} \\
\hline \multicolumn{6}{|c|}{ Carbon dioxide } \\
\hline \multirow[t]{2}{*}{$\begin{array}{l}\text { Supercritical } \\
\mathrm{CO}_{2}\end{array}$} & \multirow[t]{2}{*}{ Non polar } & \multirow[t]{2}{*}{ No } & \multirow[t]{2}{*}{$\mathrm{SFC}$} & $\begin{array}{l}\text { Lipids (fatty acids, phospholipids, MGDG, } \\
\text { DGDG) }\end{array}$ & $\begin{array}{l}{[33]} \\
{[34]} \\
{[35]}\end{array}$ \\
\hline & & & & Peptides & [36] \\
\hline \multirow[t]{2}{*}{ Liquid $\mathrm{CO}_{2}$} & \multirow[t]{2}{*}{ Non polar } & \multirow[t]{2}{*}{ No } & $\begin{array}{l}\text { Flash } \\
\text { chromatography }\end{array}$ & $\begin{array}{l}\text { Fatty acid (sorbic acid), benzoic acid (4- } \\
\text { hydroxybenzoic acid), Vitamin } \\
\text { (niacinamide), Pharmaceutical drugs } \\
\text { (antipyrine, ketoprofen, ibuprofen), } \\
\text { Nitrogen compounds (N-Benzylbenzamide, } \\
\begin{array}{l}\text { 4-dimethylamino pyridine), Alkaloids } \\
\text { (noscapin, caffeine) }\end{array}\end{array}$ & [37] \\
\hline & & & TLC & PAH (chamazulene) & [38] \\
\hline
\end{tabular}

${ }^{a} \mathrm{ChCl}$, choline chloride; EG, ethylene glycol; 2-MeOx, 2-methyloxolane; HPLC, high-performance liquid chromatography; SBWC, subcritical water chromatography; TLC, thin-layer chromatography; SFC, supercritical fluid chromatography; TPA, terephtalic acid; MGDG, monogalactosyldiacylglycerol; DGDG digalactosyldiacylglycerol; PAH, polycyclic aromatic

\section{$222 \quad$ Future trends}

223 The selection of the ideal solvent for analytical chemistry is a compromise between the

224 efficiency of extraction procedure, the analytical method, the matrix specificities and the target

225 molecules. Sustainable alternatives to common petrochemical and hazardous solvents for 226 sample preparation and analysis have been discussed in this review. Two recent success stories,

227 2-MeOx, for sample preparation, and supercritical carbon dioxide, for analytical separation

228 have been particularly emphasized. However, the panorama depicted in this paper reminds us

229 that in front of the complexity of target molecules in natural products, there is no universal

230 solvent for analytical chemistry. 


\section{References}

[1] P.A.R. Fernandes, C. Le Bourvellec, C.M.G.C. Renard, F.M. Nunes, R. Bastos, E. Coelho, D.F. Wessel, M.A. Coimbra, S.M. Cardoso, Revisiting the chemistry of apple pomace $\begin{array}{lllll}\text { polyphenols, } & \text { Food } & \text { Chem. } & 294 & \text { (2019) }\end{array}$ https://doi.org/10.1016/j.foodchem.2019.05.006.

[2] G. Catalkaya, D. Kahveci, Optimization of enzyme assisted extraction of lycopene from industrial tomato waste, Sep. Purif. Technol. 219 (2019) 55-63. https://doi.org/10.1016/j.seppur.2019.03.006.

[3] D.-L. Su, P.-J. Li, S.Y. Quek, Z.-Q. Huang, Y.-J. Yuan, G.-Y. Li, Y. Shan, Efficient extraction and characterization of pectin from orange peel by a combined surfactant and microwave assisted process, Food Chem. 286 (2019) 1-7. https://doi.org/10.1016/j.foodchem.2019.01.200.

[4] A. Mazaud, R. Lebeuf, M. Laguerre, V. Nardello-Rataj, Hydrotropic Extraction of Carnosic Acid from Rosemary with Short-Chain Alkyl Polyethylene Glycol Ethers, ACS $\begin{array}{lllll}\text { Sustain. } & \text { Chem. } & \text { Eng. } & 8 & \text { (2020) }\end{array}$ https://doi.org/10.1021/acssuschemeng.0c05078.

[5] D. Lachos-Perez, A.M. Baseggio, P.C. Mayanga-Torres, M.R. Maróstica, M.A. Rostagno, J. Martínez, T. Forster-Carneiro, Subcritical water extraction of flavanones from defatted $\begin{array}{llllll}\text { orange peel, J. } & \text { Supercrit. } & \text { Fluids. } & 138 & \text { (2018) }\end{array}$ https://doi.org/10.1016/j.supflu.2018.03.015.

[6] K. Fraige, R.D. Arrua, A.T. Sutton, C.S. Funari, A.J. Cavalheiro, E.F. Hilder, V. da S. Bolzani, Using natural deep eutectic solvents for the extraction of metabolites in Byrsonima intermedia leaves, J. Sep. Sci. 42 (2019) 591-597. https://doi.org/10.1002/jssc.201800905.

*[7] X. Liu, S. Ahlgren, H.A.A.J. Korthout, L.F. Salomé-Abarca, L.M. Bayona, R. Verpoorte, Y.H. Choi, Broad range chemical profiling of natural deep eutectic solvent extracts using a high performance thin layer chromatography-based method, J. Chromatogr. A. 1532 (2018) 198-207. https://doi.org/10.1016/j.chroma.2017.12.009.

This reference is of special interest. The authors relate the development of a new analytical method for the qualitative and quantitative analysis of NADES extracts from natural products. This HPTLC-based method is then implemented to investigate the application of various NADESs with the extraction of different groups of active compounds.

[8] B. Ozturk, C. Parkinson, M. Gonzalez-Miquel, Extraction of polyphenolic antioxidants from orange peel waste using deep eutectic solvents, Sep. Purif. Technol. 206 (2018) 113. https://doi.org/10.1016/j.seppur.2018.05.052.

**[9] H. Vanda, Y. Dai, E.G. Wilson, R. Verpoorte, Y.H. Choi, Green solvents from ionic liquids and deep eutectic solvents to natural deep eutectic solvents, Comptes Rendus Chim. 21 (2018) 628-638. https://doi.org/10.1016/j.crci.2018.04.002.

This reference is of outstanding interest and considered as a key review on NADESs. It includes historical point, overview of current applications including extraction and new perspectives.

[10] H.K. Ravi, C. Breil, M.A. Vian, F. Chemat, P.R. Venskutonis, Biorefining of Bilberry (Vaccinium myrtillus L.) Pomace Using Microwave Hydrodiffusion and Gravity, Ultrasound-Assisted, and Bead-Milling Extraction, ACS Sustain. Chem. Eng. 6 (2018) 4185-4193. https://doi.org/10.1021/acssuschemeng.7b04592. 
[11] S. Farooque, P.M. Rose, M. Benohoud, R.S. Blackburn, C.M. Rayner, Enhancing the Potential Exploitation of Food Waste: Extraction, Purification, and Characterization of Renewable Specialty Chemicals from Blackcurrants (Ribes nigrum L.), J. Agric. Food Chem. 66 (2018) 12265-12273. https://doi.org/10.1021/acs.jafc.8b04373.

[12] A.A. D'Archivio, M.A. Maggi, F. Ruggieri, Extraction of curcuminoids by using ethyl lactate and its optimisation by response surface methodology, J. Pharm. Biomed. Anal. 149 (2018) 89-95. https://doi.org/10.1016/j.jpba.2017.10.042.

[13] E. Chaabani, M. Abert Vian, S. Dakhlaoui, S. Bourgou, F. Chemat, R. Ksouri, Pistacia lentiscus L. edible oil: green extraction with bio-based solvents, metabolite profiling and in vitro anti-inflammatory activity, Oilseeds Fats Crops Lipids. 26 (2019) 25. https://doi.org/10.1051/ocl/2019024.

[14] X. Zhuang, Z. Zhang, Y. Wang, Y. Li, The effect of alternative solvents to n-hexane on the green extraction of Litsea cubeba kernel oils as new oil sources, Ind. Crops Prod. 126 (2018) 340-346. https://doi.org/10.1016/j.indcrop.2018.10.004.

[15] A.B. Zanqui, C.M. da Silva, J.B. Ressutte, D.R. de Morais, J.M. Santos, M.N. Eberlin, L. Cardozo-Filho, E.A. da Silva, S.T.M. Gomes, M. Matsushita, Extraction and assessment of oil and bioactive compounds from cashew nut (Anacardium occidentale) using pressurized n-propane and ethanol as cosolvent, J. Supercrit. Fluids. 157 (2020) 104686. https://doi.org/10.1016/j.supflu.2019.104686.

[16] S. Wang, Z. Zhang, T. Zhang, X. Wang, Extraction and Characterization of Flaxseed Oil Obtained with Subcritical n-Butane, J. Oleo Sci. 69 (2020) 1011-1020. https://doi.org/10.5650/jos.ess20051.

[17] H. Kanda, R. Hoshino, K. Murakami, Wahyudiono, Q. Zheng, M. Goto, Lipid extraction from microalgae covered with biomineralized cell walls using liquefied dimethyl ether, Fuel. 262 (2020) 116590. https://doi.org/10.1016/j.fuel.2019.116590.

[18] G. Ferrentino, S. Giampiccolo, K. Morozova, N. Haman, S. Spilimbergo, M. Scampicchio, Supercritical fluid extraction of oils from apple seeds: Process optimization, chemical characterization and comparison with a conventional solvent extraction, Innov. Food Sci. Emerg. Technol. 64 (2020) 102428. https://doi.org/10.1016/j.ifset.2020.102428.

[19] V. Rapinel, O. Claux, M. Abert-Vian, C. McAlinden, M. Bartier, N. Patouillard, L. Jacques, F. Chemat, 2-Methyloxolane (2-MeOx) as Sustainable Lipophilic Solvent to Substitute Hexane for Green Extraction of Natural Products. Properties, Applications, and Perspectives, Molecules. 25 (2020) 3417. https://doi.org/10.3390/molecules25153417.

[20] B. Ozturk, J. Winterburn, M. Gonzalez-Miquel, Orange peel waste valorisation through limonene extraction using bio-based solvents, Biochem. Eng. J. 151 (2019) 107298. https://doi.org/10.1016/j.bej.2019.107298.

[21] V. Rapinel, A. Chemat, C. Santerre, J. Belay, F. Hanaei, N. Vallet, L. Jacques, A.-S. Fabiano-Tixier, 2-Methyloxolane as a Bio-Based Solvent for Green Extraction of Aromas from Hops (Humulus lupulus L.), Molecules. $25 \quad$ (2020) 1727. https://doi.org/10.3390/molecules25071727.

[22] C. Samorì, L. Pezzolesi, P. Galletti, M. Semeraro, E. Tagliavini, Extraction and milking of astaxanthin from Haematococcus pluvialis cultures, Green Chem. 21 (2019) 36213628. https://doi.org/10.1039/c9gc01273g.

[23] I. Bettaieb Rebey, S. Bourgou, P. Detry, W.A. Wannes, T. Kenny, R. Ksouri, I.H. Sellami, M.-L. Fauconnier, Green Extraction of Fennel and Anise Edible Oils Using Bio-Based 
Solvent and Supercritical Fluid: Assessment of Chemical Composition, Antioxidant Property, and Oxidative Stability, Food Bioprocess Technol. 12 (2019) 1798-1807. https://doi.org/10.1007/s11947-019-02341-8.

[24] H.K. Ravi, M.A. Vian, Y. Tao, A. Degrou, J. Costil, C. Trespeuch, F. Chemat, Alternative solvents for lipid extraction and their effect on protein quality in black soldier fly (Hermetia illucens) larvae, J. Clean. Prod. 238 (2019) 117861. https://doi.org/10.1016/j.jclepro.2019.117861.

*[25] A. Dogan, C.C. Eylem, N.E.B. Akduman, Application of green methodology to pharmaceutical analysis using eco-friendly ethanol-water mobile phases, Microchem. J. 157 (2020) 104895. https://doi.org/10.1016/j.microc.2020.104895.

This reference is of special interest. The results of the study indicate that eco-friendly ethanol and water based mobile phase can apply in pharmaceutical analysis. It also reminds that the greenness of an analytical method should be evaluated from sampling to detection.

[26] A. al-K.F. Ali, N.D. Danielson, Micellar and sub-micellar liquid chromatography of terephthalic acid contaminants using a C18 column coated with Tween 20, Anal. Chim. Acta. 1105 (2020) 214-223. https://doi.org/10.1016/j.aca.2020.01.036.

[27] N. Doctor, Y. Yang, Separation and Analysis of Aspirin and Metformin HCl Using Green Subcritical Water Chromatography, Molecules. 23 (2018). https://doi.org/10.3390/molecules23092258.

[28] A.M. Ramezani, G. Absalan, Employment of a natural deep eutectic solvent as a sustainable mobile phase additive for improving the isolation of four crucial cardiovascular drugs by micellar liquid chromatography, J. Pharm. Biomed. Anal. 186 (2020) 113259. https://doi.org/10.1016/j.jpba.2020.113259.

[29] Y.H. Choi, J. van Spronsen, Y. Dai, M. Verberne, F. Hollmann, I.W.C.E. Arends, G.-J. Witkamp, R. Verpoorte, Are Natural Deep Eutectic Solvents the Missing Link in Understanding Cellular Metabolism and Physiology?, Plant Physiol. 156 (2011) 17011705. https://doi.org/10.1104/pp.111.178426.

[30] A.M. Ramezani, R. Ahmadi, G. Absalan, Designing a sustainable mobile phase composition for melamine monitoring in milk samples based on micellar liquid chromatography and natural deep eutectic solvent, J. Chromatogr. A. 1610 (2020) 460563. https://doi.org/10.1016/j.chroma.2019.460563.

*[31] D. Raj, Thin-layer chromatography with eutectic mobile phases-preliminary results, J. Chromatogr. A. 1621 (2020) 461044. https://doi.org/10.1016/j.chroma.2020.461044.

This reference is of special interest. This is the first study to report the successful use of eutectic mobile phases for thin-layer chromatography.

[32] N. Prache, S. Abreu, P. Sassiat, D. Thiébaut, P. Chaminade, Alternative solvents for improving the greenness of normal phase liquid chromatography of lipid classes, J. Chromatogr. A. 1464 (2016) 55-63. https://doi.org/10.1016/j.chroma.2016.07.083.

[33] T. Yamada, T. Uchikata, S. Sakamoto, Y. Yokoi, S. Nishiumi, M. Yoshida, E. Fukusaki, T. Bamba, Supercritical fluid chromatography/Orbitrap mass spectrometry based lipidomics platform coupled with automated lipid identification software for accurate lipid $\begin{array}{llllll}\text { profiling, } & \text { J. } & \text { Chromatogr. } & \text { A. } & 1301 & \text { (2013) }\end{array}$ https://doi.org/10.1016/j.chroma.2013.05.057. 
[34] M. Lísa, M. Holčapek, High-Throughput and Comprehensive Lipidomic Analysis Using Ultrahigh-Performance Supercritical Fluid Chromatography-Mass Spectrometry, Anal. Chem. 87 (2015) 7187-7195. https://doi.org/10.1021/acs.analchem.5b01054.

**[35] C. Chollet, S. Boutet-Mercey, L. Laboureur, C. Rincon, M. Méjean, J. Jouhet, F. Fenaille, B. Colsch, D. Touboul, Supercritical fluid chromatography coupled to mass spectrometry for lipidomics, J. Mass Spectrom. 54 (2019) 791-801. https://doi.org/10.1002/jms.4445.

This reference is of outstanding interest. The authors provide discussion about supercritical fluid chromatography including history, principles, particular focus on application in the field of lipodomics and future developments.

[36] M. Ventura, Advantageous use of SFC for separation of crude therapeutic peptides and peptide libraries, J. Pharm. Biomed. Anal. $185 \quad$ (2020) 113227. https://doi.org/10.1016/j.jpba.2020.113227.

*[37] R. McClain, V. Rada, A. Nomland, M. Przybyciel, D. Kohler, R. Schlake, P. Nantermet, C.J. Welch, Greening Flash Chromatography, ACS Sustain. Chem. Eng. 4 (2016) 49054912. https://doi.org/10.1021/acssuschemeng.6b01219.

This reference is of special interest. The authors provide a proof of principle for the use of liquid carbon dioxide as a mobile phase for flash chromatography.

[38] B.W. Baldwin, T.S. Kuntzleman, Liquid CO2 in Centrifuge Tubes: Separation of Chamazulene from Blue Tansy (Tanacetum annuum) Oil via Extraction and Thin-Layer Chromatography, J. Chem. Educ. 95 (2018) 620-624. https://doi.org/10.1021/acs.jchemed.7b00610. 